insects useful and noxious, and the various industries which depend on insects.

WE take the following from the Electrician:-" When a little girl is found 'playing at telephone,' and reproducing to the life the 'ways' of those who ordinarily profit by the new means of communication, the circumstance may be taken as an indication that telephony is in some localities becoming really I opular. The following sketch of a baby telephonist, 'pretending' to communicate with her papa, is from the Concord Monitor:She was a pretty child, happy-hearted, full of fun, and a great mimic. Only two summers had sent sunshine across her curls and waked to sensuous delight the infantile beauty and form. She dwelt in a pleasant home filled with creature comforts, among them the new innovation, the telephone. She had often watched this wonderful mechanism, and while she neither knew nor cared for the secrets of its operation, she had learned by heart the peculiar and one-sided formula of a telephone conversation. Unheeding that some one was watching her, the other day she put a little hand to the wall and imitated the pushing of the button on the telephone. Up went the other hand to the ear, as if holding the ebony cylinder, and the little miss went on in mimicry of her elders, in the following fashion :- 'Hello.' She then paused for an answer from the central office. 'Hello. Please hitch on Mr. — house to Mr. - office.' Pause. 'Is 'at you, papa?' Pause. 'When is you coming home?' Pause. (Turning to her dolls, the little one here spoke impatiently, 'Do you keep still ; I can't hear a word.') 'Yes.' (Rising inflection.) Pause. 'I don't know.' (In doubt.) Pause. 'Yes.' (Gleefully.) Pause. 'Why papa.' (In surprise.) Pause. And so the little one went on, maintaining perfectly an imaginary conversation, till at last she dropped her hand with a motion indicative of werriness from holding the telephone, and pronounced the conversational 'That's all ; good bye,' with all the nonchalance of a veteran."

THE Proceedings of the American Antiquarian Society, No. 74 , we learn from the American Naturalist, contains a paper by Mr. Philipp J. J. Valentini, on the Katunes of Maya history. The Katunes were a series of notable events that transpired from the time of the departure of the Mayas from their original home until their destruction. Don Juan Pio Perez, a learned Yucatecan, had found an old Maya manuscript containing this account, but failed to discover the author's name. From this precious document Mr. Valentini attempts to reconstruct the Maya chronology in the same manner that he deciphered the Mexican calendar stone. The results at which he arrives are as follows:-I. That the conquerors and settlers of the Yucatecan peninsula, as well as those of the Anahuac lakes, were joint participants in a correction of their national calendar about the year 290 B.C. 2 . That about the year 137 A.D., when a total eclipse of the sun took place, the ancestors of both nations set out from their common fatherland, Tula, or Tulapan. 3. That about the year 23I A.D. both nations made their appearance on the coast of Central America, and succeeded in conquering a large portion of the peninsula.

DR. FOREL has issued in a separate form his paper from the Archives des Sciences on the Temperature of the Lake of Geneva and other Freshwater Lakes.

THE additions to the Zoological Society's Gardens during the past week include a Bonnet Monkey (Macacus radiatus) from India, presented by Mr. C. Kerry Nicholls; a Common Fox (Canis vulpes), European, presented by Mr. E. Schweder; a Gold Pheasant (Thaumalea picta) from China, presented by Mr. James McGregor; a Welia Rail (Ocylromus australis) from New Zealand, presented by Mr. H. Frank Rose; a Brazilian Cariama (Cariama cristata) from Bolivia, presented by $\mathrm{Mr}$.
Charles Stanley Barnes; Six Mocking Birds (Mimus polyglottus) from North America, presented by Mr. W. Cross; a Gannet (Sula bassana), British, presented by Mr. George Edson; a Sloth Bear (Melursus labiatus) from India, a Common Squirrel (Sciurus vulgaris), European, four Mississippi Alligators (Alligator mississippiensis) from the Mississippi, deposited; a White lipped Peccary (Dicotyles labiatus), two Boatbills (Cancroma cochlearia) from South America, purchased.

\section{THE BRITISH ASSOCIATION}

$\mathrm{N}$ addition to the grants in the list which we gave last 1 week, the following were voted at the final general meeting :-Mr. James Glaisher, Luminous Meteors, I $5 l$.; Prof. Sylvester, Fundamental Invariants, 4ol. ; Prof. W. C. Williamson, Tertiary Flora, 2ol.; Prof. Rolleston, Prehistoric Remains in Dorsetshire, $25 l$.

The total sum voted was I, orol., considerably more than the receipts of the Swansea meeting.

It is expected that the public lectures at the York meeting next year will be given by Prof. Huxley, Prof. Tyndall, and Mr. Spottiswoode.

\section{REPOR'TS}

Report on the best means for the Development of Light from Coal-oas of different qualities, by a Committee consisting of Dr. Wm. Wallace (secretary), Prof. Dittmar, and Mr. John Pattinson, F.C.S., F.I.C. Drawn up by Mr. Pattinson.-If gas be allowed to burn under little or no pressure it gives a smoky flame of little luminosity ; when forced out under great pressure it yields a non-luminous blue flame like that of a Bunsen's burner. The aim in constructing a good gas-burner is so to regulate the supply of air and so to control pressure that the maximum amount of light may be obtained. This is best accomplished by an Argand burner.

From series of tables showing the result of experiments, the following conclusions are drawn:-The illuminating power is increased as the gas, issuing with less velocity, is mixed or brought in contact with less air. No increase in illuminating power is produced by heating the gas before its combustion. This confirms the results obtained by the London Gas Referees in 1871 . By heating the air admitted to the centre of a standard. Argand burner to $520^{\circ} \mathrm{F}$, an increase of light amounting to 9 per cent. was produced for a rise of $45^{\circ}$ in temperature. The trouble and expense of heating the air would probably prevent the adoption of this means of increasing the luminosity. With ordinary flat-flame burners the greatest amount of light is evolved under a pressure of one inch of water.

After giving measurements of the intensity of light evolved by gas burned in various varieties of burners (Bray's, Silber's, and Sugg's), the author concludes that the luminosity depends, so far as the burner is concerned, on the amount of gas burnt and on the pressure. The only burner presenting undoubted. advantages over others, and that owing to more perfect regulation of air-supply, is the Argand burner; but on account of its expense, the trouble of keeping it clean, and the necessity of employing a governor for each burner, it is improbable that it will come into general use. Governors are now constructed for single burners by Sugg, Peebles, Wright, Borradaile, and others. Such governors are of great service, not only in saving gas, but also in regulating supply and giving constancy in luminosity.

Thirtenth Report of the Committee, consisting of Prof. Everett, Prof. Sir William Thomson, Mr. G. F. Symons, Prof. Ramsay, Prof. Geikie, Mr. F. Glaisher, Mr. Pengelly, Prof. Edward Hull, Dr. Clement Le Neve Foster, Prof. A.S. Herschel, Mr. G. A. Lebour, Mr. A. B. Wynne, Mr. Galloway, Mr. Fosep $\bar{n}$ Dickinson, Mr. G. F. Deacon, and Mr. E. Wethered, appointed" for the Purpose of investigating the Rate of Increase of Underground Temperature downwards in various Localities of Dry Land and under Water. Drawn up by Prof. Everett (secretary). -Observations have been taken in the Talargoch Lead Mine, Flintshire (between Rhyl and Prestatyn), under the direction of $\mathrm{Mr}$. A. Strahan, of the Geological Survey, and Mr. Walker, Chairman of the Board of Directors of the mine.

The top of the shaft is r 90 feet above the level of the sea. The lowest workings are 900 feet below sea-level. The veins run across an angle of Carboniferous Limestone, bounded on both sides by 
faults which throw down coal-measure shale; and as the faults have a considerable inclination, the lowest workings run beneath the shale for a considerable distance. The limestone dips at angles varying from $45^{\circ}$ to $55^{\circ}$, and is of two kinds, one white and massive, the other thin bedded black with thin shale partings.

There are levels at intervals of about twenty yards vertically, in the vein, most of which have been driven for some years; but all the observations have been taken in newly-opened ground.

They have been taken by boring a hole 24 inches deep at a distance of from $1 \frac{1}{2}$ to 5 yards from the fore breast, and either on the same day or on the next day inserting one of the Committee's slow-action thermometers, with a foot of plugging consisting of dry rag and clay behind it. After an interval generally of four days the thermometer was taken out and read, then reinserted, and read again about a week later, the difference between the two readings never amounting to so much as half a degree.

The observations were taken at six different places in the mine, which are designated by the observers Stations I. to VI. ; but in one instance, that of Station II., owing to the swelling of newly-exposed shale, the hole became distorted, so that after extracting the dry rag and clay, an hour was expended in working out the thermometer, the reading of which has therefore been rejected. The following is a list of the five remaining stations, arranged in order of depth :-

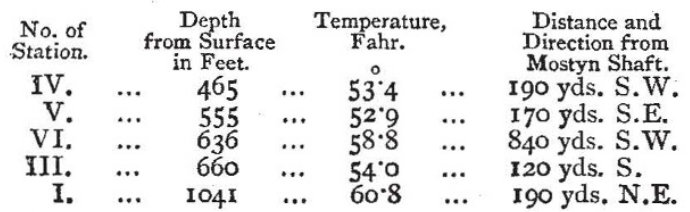

It will be observed that the order of the temperatures is not the same as the order of the depths; it therefore becomes im. portant to describe the positions with some particularity.

Stations IV., V., and III. are near together in ground plan, IV. and V. being about 250 yards apart, and III, nearly mid. way between them, and they have all the same rock overhead between them and the surface, namely, black and white limestone.

At Station I. the rock overhead consists almost entirely of sandstones and shales, with thin coal-seams. At Station VI. it consists of white limestone and shale.

It may be mentioned that the temperature at VI. was observed on three several occasions, namely, January 14, January 2I, and February 19, and was in each case found to be the same. Mr. Strahan further states that this station is near a large fault, which contains iron pyrites and gives off water charged with sulphuretted hydrogen; the temperature of the water as pumped up Walker's shaft from a depth of 770 feet, being $63^{\circ}$ at the top of the lift. It seems probable that the decomposition of this pyrites may be the cause of the exceptionally high temperature at this station.

The comparison of the temperatures will be most clearly brought out by tabulating the rate of increase from the surface down to each station, as calculated from an assumed surface temperature, which may be fairly taken as $48^{\circ}$. As all the depths are considerable, an error of a degree in the surface temperature will not have much influence on the comparison, which stands thus :-

\begin{tabular}{rrrrrrr} 
Station. & & $\begin{array}{c}\text { Depth } \\
\text { in feet. }\end{array}$ & \multicolumn{3}{c}{$\begin{array}{c}\text { Excess above } \\
\text { surface. }\end{array}$} & $\begin{array}{r}\text { Feet per } \\
\text { Degree. }\end{array}$ \\
IV. & $\ldots$ & 465 & $\ldots$ & $5 \% 4$ & $\ldots$ & 86 \\
V. & $\ldots$ & 555 & $\ldots$ & $4 \% 9$ & $\ldots$ & II3 \\
VI. & $\ldots$ & 636 & $\ldots$ & $10 \cdot 8$ & $\ldots$ & 59 \\
III. & $\ldots$ & 660 & $\ldots$ & $6 \circ 0$ & $\ldots$ & I IO \\
I. & $\ldots$ & 1, 04I & $\ldots$ & I2.8 & $\ldots$ & 8 I
\end{tabular}

Stations V. and III., which give the slowest rate of increase, are both of them in a vein called the "South Joint;" and Stations IV. and I., which agree well with each other, though differing from the rest, are both of them in another vein called the "Talargoch vein;" while Station VI. is in the "Country rock." The horizontal distance between IV. and III. is only 120 yards; but if we attempt to deduce the rate of increase from comparing these two, we have an increase of only 0.6 in 195 feet. It thus appears that, notwithstanding the proximity of the two veins, their conditions as to temperature are very different.

Widely as the results differ among themselves, they agree upon the whole in showing that the average rate of increase is slow ; and this general result is in harmony with what has been found at the nearest localities mentioned in our previous reports, namely, Dukinfield and Liverpool. Here, as at Dukinfield, all the strata are highly inclined.

Some additional observations at Dukinfield have recently been made for the Committee by Mr. Edward Garside, student of engineering in Queen's College, Belfast. The Astley Pit, in which they were taken, has now been carried to a much greater depth than it had extended at the time of Sir Wm. Fairbairn's observations, to which allusion was made in our Report for 1870. The two deepest seams of coal in it are called the "Cannel Mine" and the "Black Mine," the former being the deeper of the two ; they both slope downwards at about $15^{\circ}$, the deepest point being the far end of the Cannel Mine. The following is Mr. Garside's summary of the observations; the "surface-depth" being distinguished from the "shaft-depth," because the surface is not level, but slopes slightly in the same general direction as the seams. The shift-depth gives the difference of levels, but the surface-depth, which is practically the same as the distance of the nearest point of the surface, is what we must use in computing the rate of increase of temperature.

\begin{tabular}{|c|c|c|c|c|c|c|}
\hline $\begin{array}{c}\text { Date } \\
\text { in } \times 880 .\end{array}$ & $\begin{array}{l}\text { Seam } \\
\text { Coal. }\end{array}$ & $\begin{array}{l}\text { Surface } \\
\text { Depth. }\end{array}$ & $\begin{array}{l}\text { Shaft } \\
\text { Depth. }\end{array}$ & 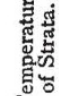 & 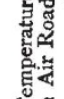 & 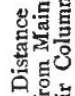 \\
\hline & & Feet. & Feet. I & Fahr & Fahr. & Yards. \\
\hline $\begin{array}{c}\text { June } 17 \\
y \quad 19\end{array}$ & $\begin{array}{l}\text { Cannel } \\
\text { Black }\end{array}$ & $\begin{array}{l}2,700 \\
2,407 \frac{1}{8}\end{array}$ & $\begin{array}{l}2,754 \\
2,631\end{array}$ & $\begin{array}{l}80 \\
80\end{array}$ & $\begin{array}{l}75^{\frac{1}{2}} \\
788^{2}\end{array}$ & $\begin{array}{l}160 \\
630\end{array}$ \\
\hline,$\quad 2 \mathrm{I}$ & Cannel & $2,416 \frac{1}{2}$ & $2,482 \frac{1}{2}$ & $8 I$ & 1.4 & 60 \\
\hline July 2 & Black & $1,987 \frac{1}{2}$ & $2,047 \frac{1}{2}$ & 74 & & $46 c$ \\
\hline
\end{tabular}

The pit is described as being entirely free from water.

Report of the Committee for making Secular Experiments on the Elasticity of Wires, by Mr. J. J. Bottomley. -The wires prepared by the Committee in Glasgow are still under experiment.

Report of the Committee on the Specific Inductive Capacity of a good Sprengel Vacuum, by Mr. W. E. Ayrton.-Boltzmann had estimated the specific inductive capacity at 9994 ; while Professors Ayrton and Perry had estimated it at 9985 . In the experiments of the committee much higher vacua had been obtained, and had found some rather remarkable and not readily intelligible results. With very high vacua the inductive capacity of the compound aluminium condenser employed appeared to be less than at slightly lower degrees of exhaustion. The method adopted consisted in applying the aluminium condenser to a modification of a Hughes induction balance in connection with a sliding condenser, a telephone, and a small induction coil.

Sir W. Thomson criticised the method as not being purely electrostatic in its nature. The discussion was continued by Mr. Gordon and Mr. Fitzgerald, who alluded to a possible connection between the fluctuations of the phenomena observed and those observed in the phenomena of Crookes' radiometer-force.

All the observations were taken with one of the committee's slow-acting thermometers, in holes drilled in the floors at the far ends of newly-opened horse-road levels; the holes being four feet deep and two inches in diameter. All the holes were free from cracks, and were in the same kind of rock-an argillaceous earth called "warren earth." They were allowed to stand for a short time, to allow the heat caused by drilling to escape. The thermometer was then inserted, and the portion of the hole between it and the mouth plugged with cotton waste and the dust which came out of the hole in drilling. After being left for forty-eight hours it was taken out and read.

The data for calculating the rate of increase are given in the first two columns below.

\begin{tabular}{ccccccc}
$\begin{array}{c}\text { Depth } \\
\text { in Feet. }\end{array}$ & & \multicolumn{3}{c}{$\begin{array}{c}\text { Temperature } \\
\text { Fahr. }\end{array}$} & \multicolumn{2}{c}{$\begin{array}{c}\text { Feet per Degree } \\
\text { from Surface. }\end{array}$} \\
$\mathbf{1}, 987 \frac{1}{2}$ & $\ldots$ & $\ldots$ & 74 & $\ldots$ & $\ldots$ & 79.5 \\
$2,416 \frac{1}{2}$ & $\ldots$ & $\ldots$ & $8 \mathrm{r}$ & $\ldots$ & $\ldots$ & 75.5 \\
$2,407 \frac{1}{2}$ & $\ldots$ & $\ldots$ & 80 & $\ldots$ & $\ldots$ & 77.7 \\
2,700 & $\ldots$ & $\ldots$ & $86 \frac{1}{2}$ & $\ldots$ & $\ldots$ & 72
\end{tabular}

The third column shows the number of feet per degree of difference from the surface, assuming the surface-temperature to be $49^{\circ}$.

Comparing the observations at $\mathrm{I}, 987 \frac{1}{2}$ and $2,4 \mathrm{I} 6 \frac{1}{2}$ feet, we have an increase of $7^{\circ}$ in 429 feet, which is at the rate of $i^{\circ}$ in $6 \mathrm{r}^{\circ} 3$ feet; and comparing the two deepest observations, we have an increase of $6 \frac{1}{2}^{\circ}$ in $292 \frac{1}{2}$ feet, which is at the rate of $x^{\circ}$ in 
45 fect. It thus appears that the rate of increase in this pit is more rapid as we go deeper. The greatest depth in Sir Wm. Fairbairn's observations was 685 yards, or 2,055 feet, and the temperature which he found for this depth was $75 \mathrm{k}^{\circ}$, which agrees to half a degree with the observations now reported.

The committee have to express their regret at the loss of two of their colleagues--Prof. Clerk Maxwell and Prof. Ansted-by death, during the past year.

Repart on the Ultra-Violet Spectra, by Prof. A. K. IIuntington. - The physical portion of the report was read in Section A. Before the Chemical Section Prof. Huntington drew attention to the following points:-The work of former experimenters on this subject is of great interest. The late Dr. Miller, in his experiments, was obliged to conclude that no connection could be drawn between the chemical composition of a substance and its power of absorbing wiltra-violet rays. Ifis method of experimentation, however, was deficient, inasmuch as he used layers of varying thickness, and in every case employed saturater solutions. His substances were not so pure as is necessary in such an investigation.

I)r. Miller also investigated the ahsorption of the ultra-violet rays hy reflection from folished metallic surfaces. The results obtained were that gold shows almost total reflection; next best is burnished lead. Other metals present a greater or less absorption. Prof. Stokes' results confirm Dr. Miller's. IIis process differed from that of I)r. Miller, inasmuch as he passed the light through a layer of the solution of the substance under ex. periment on to a fluorescent screen, while Dr. Miller photographed the spectrum. His results were of great value, and from a chemical point of view it is of interest to note that glucusides and alkaloids have great absorptive power, and that on addi. tion of acids absorption begins somewhat later than in presence of an alkali.

In $1874 \mathrm{Mr}$. Sorby constructed a spectroscope with a flunrescent eyepiece, and was thus able to observe the spectra directly. His results, though valuable, are vitiated by the impurity of the material he used.

Mention must also lie made of experiments by Prof. Cordieu, who experimented on the influence of the atmosphere in cutting off rays on the ultra-violet end of the spectrun.

Prof. Ilartley, one of the members of the Committee, has recently expcrimented on this subject, and some of the results of his research have been communicated to the Royal Society. His experiments, made with an iuproved form of Dr. Miller's apparatus, have led to interesting conclusions. He has found that monatomic alcohols of the methyl series exhibit little or no absorption. The first of the series, methyl alcohol, is, when pure, quite as "diaphanous" as water to invisible rays. Fatty acids, containing the same number of atoms of carbon as the alcohols to which they are related, have a higher absorptive power. Increascl complexity of the molecule causes increased :tbsorption. All members of the benzene series, in fact all bodies wbose constitution is best expressed by the "ring. formula," give alssurption-bands of great intensity; the hydrocarbons themselves, bowever, nccupying the lowest position in this respect. Isomeric hodies of this group differ widely in their spectrum, which thus affords a convenient means of identifica. tion. Doubly-linked bodies, such as ethene, propene, anylene, give no absorption-spectrum; and in fact the ring-form appenr. in be a sine-quân-non, for the terpenes and camplor do not absorb ultra-violet rays.

The intensity of the absorption bands of naphtbalene and anthracene is remarkable; a solution of $\mathrm{I}$ part of the latter body in 50 million times its weight of acetic acid may still be recognised,

On the Spectra of Metalloids, by Dr. A. Schuster, F.R.S.The author stated that he had consideralle difficulty in distinguishing the spectrum of an element from pound. For example, the familiar spectrum of a Bunsen's flame is ascribal by some to carbon, and by others to a hydrocarbon, the argument in favour of the latter view being that the temperaturc of the finme is nut sufficiently bigh to volatilise carbon as such. The reply to this argument is that during its passage from its compound with hydrogen to $\mathrm{CO}$ or $\mathrm{CO}^{\prime}$, the element carbon is actually libcrated, and then cxhibits the bandspectrum; and in confirmation of this theory it has been noticed that gas impregnated with a salt of a metal such as copper or iron, gives in the Bunsen's burner the true metallic spectrum and not the spectrum of a compusund. The same argumert applics here, for the metal is actually liberated during its passage from (say) the chloride to the oxide. Besides, the band spectrum is seen still more effectively when cyanogen is burned, even when dried as perfectly as possible. This band-spectrum is seen in the sun's rays, and it is highly improbable that cyanogen should be able to resist such an enormously bigh temperature.

The author then considered the question :- Why should an element give different. spectra at different temperatures? Bands are characteristic of compounds, and at low temperatures elements show a banded spectrum. At higher temperatures such spectra become simpler, and the evident conclusion is that complex molecules of the elements are dissociated into those of a simpler order. This view is rendered highly probable by the fact that the spectrum of mercury is a constant one, and that no known increase of temperature alters its character; now, assuming the molecule of hydrogen to consist of two atoms, that of mercury consists of a single atom, and it is evident that no simplification is possible.

The changre of the spectra of chlorine, lromine, and indine, as the temperature is increased would scem to corroborate Frof. Victor Meyer's recent conclusions with regard to the molecular complexity of these elements.

It was also suggested that the spectrum of an clcment might vary according to the compound from which it is liberated. Were it possible to decompose carbon monoxide and dioxide, and to obtain the spectrum of the single carbon atoms which they contain, it would probally differ from the well-known banded spectrum of carbon which there is reason to suppose is that of at least a two-atom molecule.

Mr. W. Chandler Roleerts pointed out that Prof. IViedemann has unlertaken measurements to ascertain whether a change of temperafure takes place during alteration of the spectrum, and hoped that interesting results would be ubtained.

Report of the Commillee on Erratic Blocks, presented by the Rev. II. W. Crosskey. (Abstract.)-Although the destruction of erratic blocks is proceeding with considerable rapidity, the Committee were alle to report the discovery and preservation of some important specimens.

One of the most remarkable blocks of Shap granite yet olserved is described by Mr. J. R. Dakyns at Seamer Station, near Scarborough. It measures roughly $5 \mathrm{ft}$. $8 \mathrm{in.} \times 4 \mathrm{ft}$. 10 in. $\times 4 \mathrm{ft} .3 \mathrm{in}$., and was fairly imbedded in gravel, forming the summit of a well-marked terrace 225 fect above the sea-level. This boulder is specially interesting in that it is the only boulder of Shap granite in the neighbourhood whose position in the beds is known; and this position shows that at the age assigned to the gravels (which is a comparatively recent une) icelerg's must have been floating about. It has been preserved in the garden of the Station House.

The report records particulars of boulders discovered in the neighbourhond of Urmston, near Manchester, and also of a large number both of isolated boulders and groups of boulders observed in Leicestershire by Mr. J. Plant.

Mr. P'engelly furnishes a very interesting part of the report in an account he gives of some transporter blocks and accumula. tions of blocks which he has observed in South I)evon, the transposition of which it does not secm altogether possible that the action of water alone could lave effected. A block of greenstone occurs in the village of Kingston, Sonth Levon, mensuring $4 \times 2 \times 2$ feet, and weighing upwards of $a$ ton. There is a mass of greenstone figured on the map of the Survey, extending to alsout a mile west-north-west of Kingston, where it makes its nearest approach to the village. I3locks of quartzite bave been found in great abundance in the parishes of Diptford and Morleigh. They can be traced to their source on the higher levels of the neighbourhood; a bed of yuartzite identical in character with the travelled l, locks being interbedded conform. ally with the ordinary slaty I) vounian rocks of the district. There can be no doubt that the blocks have been transported from south in north, and from higher to lower ground. The gradient, however, is very slight, and as almost all the blocks are very angular as well as large, it is difficult to suppose that their transportation was the result of nothing more than running water.

A block of greenstone occurs near Diptford Court, weighing filly 1.75 ton. A mass of igneous rock apparently of the same kind is found at a distance of five miles due south of the woukler, and another about the same distance north.

The blocks locally termed in South-Western Devon "Whita- 
kers", are described in the report. They are composed of white opaque quartz, having in some cases a laminated structure, and traversed occasionally with veins and crystals of the same material. That the blocks bave travelled a considerable distance cannot be doubted; and that their transportation was not effected by the action of water only appears proved. The blocks are ail more or less rugged and sub-angular, although without any decided traces of glacial polish or scratches. They occur most plentifully on the higher ground.

They have been so largely utilised by the farmers and for artificial rockeries that it is to be fcared, unless care is taken to prevent it, those now remaining on the spots they have so long occupied undisturbed may altogether disappear.

The report concluded with an appeal to local observers to report upon the erratics still unrecorded before the work of destruction is completed, and evidence throwing light on difficult problems of glacial geology is destroyed.

Report on the Explonation of Caves in the South of Ireland, by Prof. A. Leith Adams. Includes a Report by Mr. R. I. Ussher.-Describes caves at Carnigea Gower, four miles south of Middleton. Stalagmite floor - on sandy clay; beneath the stalagmite was much charcoal, the roof had an opening to the surface, down which much kitchen rubbish had been thrown associated with hammer stones, flint flakes, iron implements, and remains of recent animals. $\Lambda$ report was read on the implements, by Mr. R. Day, which are of no great antiquity; one piece of pottery was believed to have a Roman (capital) letter inscription.

Report on the Carboniferous Polyzoa, by W. G. R. Vine.Discusses the character of the genus and species and the views held on them by the earlier workers, and after a comparison of the specific forms be relegates to each of these the precise grenera to which they belong.

Report on the "Geological Record," by Mr. W. Whitaker.Four volumes have been published, each of which gives an abstract of all geological work done throughout the world, for one year; they contain an average number of 20,200 entries in cach volume.

Sixteenth Report of the Committee appointed to Explore Kent's Cavern, by Mr. Pengelly. - The deposits passed through in the cavern were :-

$$
\begin{aligned}
& \begin{array}{l}
\text { Iron and } \\
\text { bronze. }
\end{array} \text { BLACK MOULD. Roman Remains (Ovine). }
\end{aligned}
$$

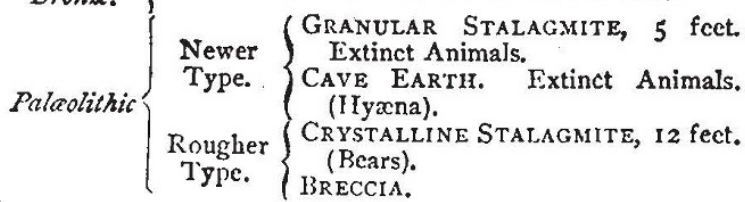

Work commenced in March, 1865, by excavating down to 4 feet throughout the whole cavern; fin:shed in November, 1879 , the floor had at that time been so excavated, at a cost of 1,850 . to the Association. A further grant was then given to lay bare the limestone floor; and subscriptions from private sources amounted to $5 \mathrm{I} l$. received, which enabled the base of the cave deposit to he cxcavated for a length of 132 feet. Occasionally stalagmitic fragments occurred on the base of the breccia, resting on the rock. On June 19, 1880, the work was suspended, it having only yielded seventeen finds-amongst them a flint nodulc, which bad not heen touched by the implement maker-which are of greater rarity. Archasological finds were more numerous than remains of animals; the implements correspond to those of the oldest river gravels in type. Referred to the good work done by $\mathrm{Mr}$. George Smerdon, the foreman of the workmen during sixteen years, who has become crippled with rheumatism, brought on by exccution of the work, and suggested the desirability of raising subscriptions to purchase for him an annuity of rol. a year.

Report of the Commitlec, consisting of Mr. Fames Hiynood, Mr. Shatn, Mr. Stcph'n Bourne, Mr. IVilkinson, the Rev. W Delaney, and Dr. F. MI. Ciludstone (Sccretary), appointed for the furpose of reporting whather it is important that HT.M. Instectors of Elementary Schools should be appointed with reference to their ability for examining the scientific spccific subjects of the Code in addition to other matters. - The Committee nominated at Shefficld for the purpose of considering "whether it is important that H.M. Inspectors of Elcmentary Schools should be appointed with reference to their ability for examining the scientific specific subjects of the Code in addition to other matters," have received a considerable amount of evidence upon the subject, and beg to report as follows:-

I. It has come to their knowledge that the teaching of the scientific specific subjects is practically discoaraged by the incapacity of many of II.M. Inspectors to examine in them.

2. This incapacity is explained by the fact that the Inspectors are not generally chosen so much for their fitness to judge of such educational work, as on account of their high scholarship, or through political patronage.

3. In the opinion of this Committee there might be an examining body for H.M. Inspectors, composed of three of the most experienced of the present senior Inspectors, associated with a similar number of the Science Examiners of the Science and Art Department. The examination should be thrown open to elementary teachers, and the candidates might be tested in the practical work of examination in one of the Central Elementary Schools in London.

4. The Committee believe that the opening of the Inspectorship to fully qualified elementary teachers would tend to raise the esprit de corps of the profession, and improve the character of both inspector and teacher.

5. The Committee are further of opinion that whtile a university degree may be fitly regarded as a test of schotarship, it is not a test of the particular qualifications for an examiner, and therefore is not sufficient in itself to guarantee the holder thereof as worthy the position of Inspector. There appears to be no reason why academical honours should be made an indispensable condition of appointment.

6. The Committee recommend that a memorial be presented to the Lords of the Committee of Privy Council on Education embodying the above conclusions.

Report of the Committee, consisting of Dr. Pye-Smith, Prof. M. Foster, and Prof. Burdon Sanderson (Secretary), afpointed for the purpose of investigaling the Inftuence of Bodily Exercise on the Elimination of Nitrogen (the Experiments to be toridteted by Mr. North). -During the past yenr four serties of prelminary experiments, each of several wceks' duration, have been made by the Committee on the subject, the expenses of which have been met from other funds. In the course of these expcriments unexpected difficulties have been encountered relating to method. The most serious of these difficulties having now been for the most part overcome, wc are in a position to proceed with our inquiries next winter, and have therefore to request that the sum of $50 l$., previously granted to us, may again be placed at our disposal.

\section{SFCTION A-Mathematical and Pirysical}

On some Lawis which regulate the Succession of Temperature and Rainfall in the Climate of London, by $\mathrm{H}$. Courtenay Fox, M.R.C.S. - The following paper is an attempt to answer the question: Is there to be found any definite relation between extremes of rainfall or temperature in any month or season, and the weather of the month or season next following?

The data used by me are the same as those upon which the foregoing paper on "Synchronisms" is based, viz, the wonthly temperature and rainfall for the Royal Observatory for sixty-six years-1815 to 1880 . In accordance with the principles explained by me at p. 277 of the Report of the British Association for 1879 , each month is clistributed under the five heads of temperature-according as it was very cold, cold, average, warm, or very warm ; and under the five heads of rainfall-according as it was very dry, dry, average, wet, or very wet.

I have presented three tables, which show, for each month or season which is classed under one or other of the extremes of rainfall or temperature, the character, in these respects, of the month or season next following.

A careful study of these tables enables us (whilst omitting all those results which are of an ambiguous character) to state the following definite propositions:-

1. A cold spring is very prone to be followed by a cold summer, a cold summer tends to be followed by a cold autumn, and a cold autumn has a slight tendency to be succecded by a winter of low temperature.

2. Warm summers are grenerally followed by warm autumns.

3. In no fewer than eight out of the twelve months (that is in cvery one except Fcbruary, March, May, and October), very low temperature tends to be prolonged into the succeding month. 
4. If June, July, August, or December be warm, the next month will probably be a warm one also.

5. Two months, June and July, tend, when very dry, to be followed by dry ones. On the other hand, a dry August indicates the probability of a wet September.

6. A wet December is apt to be succeeded by a wet January. In addition to the foregoing, there are also a few instances in which the rainfall of certain months appears to be definitely related to antecedent extremes of temperature, and vice versâ. Thus

7. If August or September be warm, the ensuing September or October inclines to be wet. If, on the other hand, September or November be cold, the succeeding October or December is likely to be a dry month.

8. If February, June, or July be very $d r y$, the next month has a strong tendency to be warm.

9. If January, March, or April be zeet, we may also expect the next month to be a warm one. But a wet May or July gives a strong probability of cold weather in June or August respectively.

Mr. W. H. Preece read a paper On the Best Form to give to Lightning Conductors. The question was whether the lightning conductor should be a solid rod, or tubular, or flat. Snow Harris, Prof. Henry, M. de Melsens, and M. Guillemin advocated straps of great surface. Faraday strongly maintained that there was no advantage in strap or tube forms, as the surface does nothing in conducting the current. Mr. Preece had obtained the use of Dr. De La Rue's magnificent batteries, and had procured conductors of equal material, length, and weight, but differing in form. A condenser charged from 3,400 cells afforded a very powerful source of electricity, more than fortytwo microfarads being thus available to produce an enormous spark. Experiments made by heating and deflagrating wires through the different conductors left no doubt that these discharges do obey the law of $\mathrm{Ohm}$, and therefore that the additional surface of flat and tubular conductors is of no advantage in their conductivity.

Prof. Osborne Reynolds rather doubted the conclusions of Mr. Preece, on account of our not knowing the conditions under which the electricity passes from the air into the surface of the conductor. Prof, Ayrton thought the experiments should be tried with much greater difference of potential. The 3,000 cells would not produce a free spark of more than $\frac{1}{40}$ of an inch long, whereas flashes of lightning might extend over miles.

Mr. Preece, in replying, pointed ont that increased surface, though increasing its inductive capacity, did not add to its efficiency, which depended only on its conductivity.

$\mathrm{Mr}$. Preece also communicated an observation on the peculiar behaviour of copper wires. Very powerful discharges of electricity were found to increase the conductivity of newly-drawn copper wires by an appreciable percentage. Leaden wires showed no such changes. In the subsequent debate it appeared that the opinion was that the effect of the first current was to anneal the wire.

On the Necessity for a regular Inspection of Lightning Conductors, by Richard Anderson, F.C.S., A. Inst. C.E. -The author referred to a paper by M. W. de Fonvielle, "On the Advantage of keeping Records of Physical Phenomena connected with Thunderstorms," read before this Association in 1872. M. de Fonvielle recommended to the attention of the members the steps which had been taken by the French Government for obtaining information regarding thunderstorms, and suggested that the Association should institute some organisation for the collection of such data ; arguing that it would be of much value to science, as well as to the public. Nothing, however, has been done by the Association since 1872; and the author not only confirmed the conclusions at which $\mathrm{M}$. de Fonvielle arrived as to the desirability of collecting such data, but was of opinion that the organisation should go further, and arrange for a regular inspection of all public buildings which had lightning-conductors a.pplied.

The necessity for this he demonstrated by adducing a number of striking cases where damage, more or less severe, had occurred to buildings, even though having lightning-conductors attached to them. The cases now cited, he explained, were supplementary to those communicated in his paper on a similar subject to the Association in 1878 . A few of the cases were as follows :-

In October, 1878 , an elevated building situated at the back of Victoria Station, occupied as a furniture repository, was struck by lightning and sustained damage, although furnished with a $\frac{3}{4}$-inch by $\frac{1}{8}$-inch copper band lightning conductor and a tube of $\frac{5}{5}$-inch diameter rising above the iron crestings on the tower. The lightning shattered the cresting and bent the point of the lightning-rod, besides doing other damage to the building. On testing, the author found the resistance very great, and on opening out the earth-terminal found it imbedded in concrete.

On June 26 last, lightning struck All Saints Church, Lambeth, doing considerable damage, although there was a $\frac{3}{8}$-inch diameter copper-rope conductor on the west gable, with a copper tube rising 18 inches above. A stone cross about 50 feet from the conductor was thrown down, injuring the roof of the north aisle. On testing the conductor, the author found that it had no "earth" whatever, the rope being simply placed in 2 inches of loose rubbish. The copper was of very inferior quality ; conductivity being 32 ' Io per cent., or about double that of iron.

The author quoted also a few cases from his recent work on "Lightning-Conductors, their History," \&c:-

In August, 1878, the Powder Magazine at Victoria Colliery, Burntcliffe, Yorkshire, was struck by lightning, though furnished with a conductor, 13 feet above the building, and terminating in I 3 feet of clayey soil. The building was blown to pieces. On testing the conductivity of the copper, it was found to be $39^{\circ} 2$, instead of 92 to 94 per cent. The conductor was insulated from the building and from a large iron door, which it ought not to have been.

The author concludes from this evidence that it is not sufficient merely that rods of copper should be attached to a building, but it is necessary that after being fixed they should be regularly inspected, to see if they are in good order, so as to be really efficacious.

Sir Wm. Thomson gave a communication On a Method of Measuring Contact Electricity. Sir W. Thompson had devised this method at the time when Hankel published his results in 186r. A method identical with it had lately been described by $\mathrm{M}$. Pellat, and consisted in employing a small electromotive force in connection with a dividing resistance slide, to give a counterbalancing electromotive force to that produced by contact.

Sir W. Thomson next described $A$ Method of Determining without Mechanism the limiting Steam Liquid Temperature of a Fluid. This was a simple apparatus, consisting of a closed glass tube containing liquid sulphurous acid filled to a sufficient height to insure that the liquid in the lower half will expand to the top. Prof. W. Ramsay criticised the proposal, and stated that he had found an apparatus in which a screw was employed to produce increase of pressure instead of using the expansion of the liquid itself. With this apparatus he had repeated Andrews' research on a large number of substances.

Mr. G. F. Fitzgerald read a paper On the Possibility of originating Wave-disturbances in the Ether. This was a mathematical paper, in which, by comparing the equations of Maxwell's theory of the propagation of electric action through a medium with those of direct action at a distance, he deduced the conclusion that electric currents and systems cannot originate in the ether such disturbances as those of light.

Mr. R. M. Shida gave an account of A New Determination of the number of Electrostatic Units in the Electromagnetic Unit. The value $V$ of this ratio he deduced was $294^{\circ} 4 \times 10^{8}$.

M. Wilfrid de Fonvielle exhibited his magnetro-electric gyroscope, which has been already described in our pages.

$M$. Janssen sent a communication to the Section, which was read by the Secretary, apon his recent researches $O n$ the obtaining Positive Photographs by Prolonged Exposure.

$\mathrm{Mr}$. Wiesendanger showed a new electromotor, which will be described hereafter in our pages.

Mr. Philip Braham exhibited an ingenious adaptation of limelight for microscopic illumination, and also described a simple instrument for detecting polarised light.

On the Best Form of Magnet for Magneto Machines, by W. Ladd.-At the British Association meeting at Dundee in 1867, I made some remarks upon different forms of magnets, and exhibited these diagrams, showing, by the "lines of force" naturally arranged, the great superiority of the circular magnet where an armature is to be employed.

Since that time some thousands of that form of magnet have been made for medical, mining, and other purposes.

Some months ago, in conversation with M. Bregnet of Paris, I showed him these same diagrams, and he was very much impressed with their importance; he has since then constructed a machine, using the Gramme armature, and with a smaller quantity of steel in the magnets he has made a far more powerful 
machine than hitherto constructed with either the Jamin or the ordinary horse-shoe form. It is also more symmetrical in appearance, and occupies less space.

With this machine I can heat to incandescence nineteen inches of platinum wire by four turns of the handle, while to heat fourteen inches of the same size wire by a machine having a Jamin magnet it took ten turns of the handle.

Mr. Bottomley followed up his report with a paper On the Elasticity of Wires. This paper related the effect of adding loads gradually to a wire which carried a load, and which was found to increase in the limit of breaking strain when longer times were allowed to elapse between the successive increments of the load. A charcoal iron wire which bore a load of $4 \mathrm{I}$ lbs. when suddenly loaded would support $52 \mathrm{lbs}$. after having borne the load of $4 \mathrm{I}$ lbs. for 790 hours. Some remarks were made by Sir W. Thomson and by Dr. Siemens, who referred to some recent experiments made in Germany of the stretching of wires and rods of steel, which tended to show that protracted tensile strain affected the chemical condition in which the carbon of the steel was combined with the iron in it. Mr. J.E. H. Gordon referred to the connection between the mechanical and magnetic properties of steel under different conditions.

On the Comparison of Declination Magnetographs at various Places, by Prof. W. G. Adams. - This paper was accompanied by diagrams of simultaneous magnetic disturbances at St. Petersburg, Kew, and Vienna, showing that many of the sudden magnetic disturbances occur simultaneously over very great areas, but that in some cases the variations were in opposite directions. In the debate which followed Sir Wm. Thomson spoke of these observations as beginning to open out a glimpse of the true cause of the magnetic storms. He observed that if similar records of the other magnetic elements, inclination and intensity, could be procured, we should know definitely whether these disturbances were due to any changes of the magnetism of the earth itself, or whether they were due to an external magnetic action. Mag. netic observations had been going on for forty years, and it was a reproach that more had not hitherto been done. $\mathrm{He}$ also referred to the alleged connection between auroræ and magnetic storms. Mr. J. Glaisher and Staff-Commander Creak mentioned cases of sudden magnetic disturbances. Capt. Creak recalled the observations of the Arctic expeditions of $1875^{-6}$, when a deflection of $5^{\circ}$ was observed within forty minutes, the Kew records showing synchronously a smaller fluctuation. He argued that an observing, station in a more northerly latitude was necessary. Mr. W. H. Preece recounted a magnetic and electrical storm which affected. Ireland and the west of England on August 12. Magnetic disturbances always were accompanied by earth currents which affect the telegraph-wires. The same storm affected even the Atlantic cables and the Cape cable. He believed they would be found to have affected the whole earth. The electromotive force on this occasion, through the Atlantic cable, was about as great as that of 300 Daniell's cell, or more exactly one volt per 6.6 miles. Capt. Creak also exhibited the new Admiralty charts of the magnetic variation for 1880 .

Prof. G. H. Minchin read a communication On Photoelectricity. $\mathrm{He}$ had obtained feeble currents from two silver plates coated with sensitive films of iodide, chloride, or bromide of silver, dipping into a common fluid, and then one of them exposed to the light. He had also observed that preparations of fluorescent and phosphorescent bodies upon silver plates acted similarly.

Prof. Silvanus P. Thompson gave a paper On Electric Convection Currents, pointing out their analogies with true conduc. tion currents, and of currents of electrolytic conductivity in respect of electro-magnetic phenomena. The application to ring-figures produced by disruptive convection and by electrolytic conduction was considered, and their deformation in the magnetic field. It was pointed out that considerations of a similar nature had been advanced by Prof. Ayrton at an earlier date.

Experiments on Thin Films of Water, with regard to the Absorption of Radiant Heat, by the Hon, F. A. R. Russell.The experiments, the general results of which are given below, were made with the object of ascertaining the diathermancy of water in very thin films, and these experiments afforded incidentally an opportunity of observing the behaviour of films subject to varying conditions.

The arrangement of instruments was similar to that illustrated at p. 383 of Prof. Tyndall's "Heat as a Mode of Motion." The instruments used were: a dead-beat mirror galvanometer and scale, a thermopile, and a screen. The soap film was carried by a piece of a cork sole perforated by a hole slightly larger than the hole in the screen, about $\mathrm{I}_{2}$ inch in diameter. The sources of heat were (I) a copper or iron ball heated from behind by a small gas flame; (2) a gas flame from a Bunsen burner and (3) a hydrogen flame in air

The film was mostly made from a solution of about half a drachm of shavings of Castile soap, dissolved five to fifteen minutes in about five cubic inches of water, at $60^{\circ} \mathrm{F}$.

The film, soon after being placed perpendicularly at the orifice in the screen, exhibited coloured bands, which descended in regular succession until the last band appeared, which contained a bright blue line. The descentof the bands continued at a slackened rate till the grey, and finally the black, occupied a portion of the upper half of the film, which half was alone subject to experiment. A condition more or less of equilibrium then prevailed, the tension of the black portion counteracting the force of gravity. A light yellow or bronze was always the last colour to appear, and preceded the white or grey, which again was succeeded by black. When there was any black in the film, the bursting of the film was marked by a slight click or snapping sound. The best films lasted frequently between ten and thirty minutes, and sometimes the black portion alone was under observation fifteen or twenty minutes.

The following table shows the absorption per cent. for each of the three sources of heat, and the thickness of the film, as derived from a table in Watt's "Dictionary of Chemistry," giving Newton's thicknesses of thin films of air, water, and glass. A table in Cooke's "New Chemistry" gives the thicknesses of soap-films as considerably greater than those stated in Newton's table. The "light film" of Cooke corresponds to my "grey," and his "grey" to my " fine grey." Newton's "white" corresponds to my "grey." The refractive index of the solution ased by me was $r \cdot 34$ and $r \cdot 35$, a little higher than that of pure. water.

\begin{tabular}{|c|c|c|c|c|}
\hline State of Film. & Metal. & Gas. & $\begin{array}{c}\text { Hydro- } \\
\text { gen. }\end{array}$ & 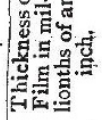 \\
\hline 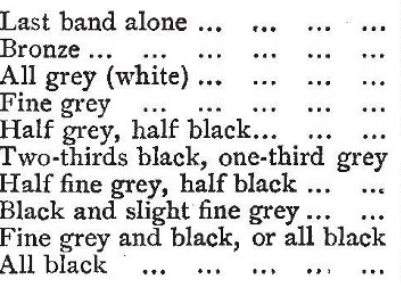 & $\begin{array}{l}9 ? \\
6 \\
4.7 \\
= \\
= \\
0.7 \\
0.29 \\
0.29\end{array}$ & $\begin{array}{l}8 ? \\
5 \cdot 7 \\
-3 \cdot 4 \\
2 \cdot 9 \\
x \cdot 6 \\
= \\
= \\
x \cdot 5\end{array}$ & $\begin{array}{l}\frac{-}{4 \cdot 5} \\
\frac{-}{1 \cdot 6} \\
\frac{-}{1 \cdot 2} \\
0 \cdot 6\end{array}$ & $\begin{array}{l}8 \cdot 3 \\
5 \cdot 2 \\
3 \cdot 9 \\
1 \cdot 8 \\
2 \cdot 3 \\
r \cdot 8 \\
r \cdot 34\end{array}$ \\
\hline
\end{tabular}

\section{SECTION B-Chemical Science}

On the Influence of Water on the Union of Carbonic Oxide with Oxygen at a High Temperature, by Harold B. Dixon, M.A.The author obtained the curious result that a mixture of carbonic oxide and oxygen in such proportions as to form carbon dioxide, when free, or nearly free, from water, does not explode, either by a direct discharge from a Leyden jar or when sparks are passed through it from a Ruhmkorff coil. By allowing a minute portion of aqueous vapour to mix with the gases, explosion immediately takes place on the passage of the spark. In presence of a very small trace of water, combustion takes place, but slowly, not with explosive energy. The author suggests as an explanation the following equations :-

$$
\begin{aligned}
& \mathrm{CO}+\mathrm{H}_{2} \mathrm{O}=\mathrm{CO}_{2}+\mathrm{H}_{2} \\
& \mathrm{H}_{2}+\mathrm{O}=\mathrm{H}_{2} \mathrm{O} .
\end{aligned}
$$

Prof. Williamson suggested that it would be interesting to determine the inferior limit to the power of water vapour in causing an explosion, and that Mr. Dixon would probably extend his research in this direction.

Prof. Harcourt pointed out that various other similar instances are known, among others the impossibility of causing union of calcium oxide and carbonic anhydride, in absence of water, and the refusal of dry chlorine to act on hot sodium.

$\mathrm{Mr}$. Thomas noticed that in mixtures containing large amounts of marsh-gas the presence of water vapour also influenced the rapidity of explosion. 
Prof. Silva remarked that the influence of diluents may have a contrary effect from that of water-vapour, and that the question is worth investigation.

Metallic Compounds containing Organic Radicals, Part I, by J. Sakurai. -The author has succeeded in obtaining a compound of methylene iodide, $\mathrm{CH}_{2} \mathrm{I}_{2}$, with mercurous iodide, $\mathrm{Hg}_{2} \mathrm{I}_{2}$, of the formula $\mathrm{CH}_{2} \mathrm{IHgI}$. It is a white crystalline substance, insoluble in water, cold alcohol, ether, chloroform, and ethylic iodide. It is soluble in boiling alcohol and in methylene iodide. It melts at $108^{\circ}-109^{\circ} \mathrm{C}$

Besides this substance, another, insoluble in all ordinary solvents, is produced, which possesses the formula $\mathrm{CH}_{2}(\mathrm{HgI})_{2}$. Chlorine and bromine act on these substances, forming methylene chlorides or bromides, and halogen salts of mercury. The author proposes to attempt to produce the zinc and sodium analogues of this body.

On some Relations betrueen the Atomic Volumes of Certain Elements and the Heat of Formation of some of their Compounds, by Walter Weldon, F.R.S.E.- It has been observed that the heat evolved by the union of chlorine with a metal is greater than that of bromine, and that the heat given off by bromine is greater than that by iodine. In a similar manner oxygen gives off more heat than sulphur. Berthelot has observed that positive elements obey the same rule, but that there are some exceptions caused par diverses circonstances mal connues. That the heat of combination is inversely proportional to the atomic weights of the reacting elements is sometimes the case, but is not a general law; but on comparing the heat evolved by combination of positive elements with their volumes, a direct numerical proportion is observable. To this law there are two exceptions, viz. cadmium and manganese. Cadmium is usually classed along with zinc and magnesium, although it closely resembles indium. It compares with magnesium, but not with zinc. The atomic volume of cadmium is greater than that of zinc, yet the heats of formation of its chloride, oxide, \&c., are less than those of zinc. The heat of formation of indium com. pounds, which have not yet been observed, should be greater than those of zinc. In the same way the heats evolved during formation of compounds of manganese are greater than those of iron, yet the atomic volume is less. Either this case is exceptional, or manganese does not belong to the iron group.

In over 100 instances it has been observed that molecular heats of formation of elements of the same group divided by the atomic volumes of the electro-negative elements give numbers either identical with, or bearing some simple relation to, each other.

After some complimentary remarks from Prof. Williamson, Prof. W. Ramsay pointed out that the heats evolved by the combustion of allotropic modifications of carbon and phosphorus bore the same relation to each other as their specific volumes, and hinted that the heat evolved by the combination of elements of the same group with other elements bore some remarkably simple proportion to the relation of the number of atoms in the complex molecules of the solid elements.

On the Specific Rotatory Power of Cane and Invert Sugar, by Alfred H. Allen.--The author points out that on inverting sugar its weight is increased by absorption of water, and that allowance is not usually made for this fact. He has therefore calculated the following corrected table for $S_{j}$ :-

$$
\begin{array}{lcccc}
\text { Cane-sugar } & \ldots & \ldots & \ldots & +73.8 \\
\text { Invert sugar } & \ldots & \ldots & \ldots & -25.6 \text { at } 15^{\circ} \mathrm{C} . \\
\text { Dextrose } \ldots & \ldots & \ldots & \ldots & +57.6 \\
\text { Lævulose } . . . & \ldots & \ldots & \ldots & -108.8 \text { at } 15^{\circ} \mathrm{C} .
\end{array}
$$

The deviation for a plate of quartz $I \mathrm{~mm}$. thick is under similar conditions $24^{\circ}$ for its transition tint, and $21^{\circ} 66^{\circ}$ for the sodium ray. Hence the corresponding values for $S_{D}$ may be calculated by multiplication by $\frac{21^{\cdot} 66}{24}=0^{\circ} 9025$.

On the Identification of the Coal-Tar Colours, by John Spiller, F.C.S.- The process recommended is the action of sulphuric acid on the dyeing material, taken in conjunction with the shades produced on, and the tendency to dye silk, wool, or cotton. The most remarkable reactions are the following :-Magdala-red with sulphuric acid gives a blue-black; Saffranin, a grass-green, becoming indigo.blue on strongly heating; Chrysoïdin, deep orange, turning almost to scarlet on heating; Alizarin, ruby red, or maroon; Eosine, golden yellow; Primrose (naphthaleneyellow), first yellow, then colour discharged; Chrysaniline, brown fluorescence; Aurine, yellowish brown; Atlas-orange, rose-colour, changing to scarlet on heating; Atlas-scarlet, no alteration; Biebrich-scarlet, $\mathrm{R}$, blue-black; ditto, $\mathrm{B}$, bluegreen ; Aniline-scarlet, permanent golden yellow; Indulin, slaty blue to indigo; all violets give a yellow, or brownish yellow; Phenyl and diphenylamine blues, dark-brown solutions; Iodine and malachite greens, bright yellow solutions, the former giving off iodine on heating; lastly, Citronine, a pale cinnamon or neutral tint.

On the Density of Fluid Bismuth, by W. Chandler Roberts, F.R.S., and Thomas Wrightson, C.E.- The density of bismuth, just molten, was determined by a modification of the usual process for determining the specific gravity of liquids devised by Mr. R. Mallet, and was found to be $10^{\circ} \mathrm{O} 39$, as a mean of three experiments. By an apparatus termed the oncosimeter, which admits of the weight of a ball of metallic bismuth being taken in molten bismuth by means of a delicate spring balance, its mean specific gravity deduced from six experiments was found to be I0.055; that of solid bismuth is 9.82 .

On Crystals of $\mathrm{HgHSO}_{4}$, by P. Braham.-Mercury, when left in contact with sulphuric acid for two years, deposits extremely deliquescent crystals of the above formula.

On the Trealment of Complex Ores containing Zinc, by E. D. Parnell. - The presence of zinc renders the extraction of lend and copper from their ores so difficult that manufacturers reject them ; nor are zinc ores containing less than 25 per cent, of zinc adapted for the extraction of that metal.

Further Notes on Petroleum Spirit and Analogous Liquids, by A. H. Allen,-To distinguish petroleum spirit from shale naphtha and from benzene, mix one volume of boiled carbolic acid with three volumes of these liquids. The carbolic acid refuses to mix with the former, but mixes with the two latter. On similar treatment with coal-tar, pitch, petroleum spirit and shale naphtha do not mix, whereas benzene does. With carbolic acid, burning oil from shale can be distinguished from kerosene, the burning oil from petroleum, for the former is not miscible, whereas the latter turns violet, and partially mixes; and if warmed, crystals of carbolic acid separate on cooling. By treatment with nitric acid and with bromine, it was shown that naphtha from petroleum contains 80 per cent. of paraffins and 20 per cent. of olefines; photogene, 55 to 80 per cent. of paraffins, and that wax consists entirely of paraffins; whereas shale naphtha contains 75 to 90 per cent. of olefines; photogene from the same source, 60 to 65 per .cent. of olefines, and that the lubricating oil consists entirely of olefines.

On the so-called Normal Solutions for Volumetric Analysis, by A. H. Allen.-This communication was a recommendation that the various different meanings of the term "normal" be done away with, and that a normal solution be understood to be one containing in $\mathrm{r}, 000$ cub. cents. such an amount of reacting body as will combine with, replace, or oxidise one gram of hydrogen.

On the Determination of the Loss of Heat in Steam-boilers, arising from Incrustation, by William Thomson.-This plan consists of evaporating the various waters in vessels exposing an cqual surface of each, care being taken to keep the total amount constant by means of a constant supply. After a given time the remainder is measured and the ratio calculated. Deposit of incrustation greally impedes evaporation.

On the Identification of the Ink used in writing Letters and Documents as Evidence in Cases of Libel, Forgery, \&c., by W. Thomson, F.R.S.E.-The author has observed that different specimens of writing give different coloured reactions with various reagents, such as sulphuric, hydrochloric, nitric, or oxalic acid, or by caustic soda, solutions of bleaching-powder, and chlorides of tin. Such differences may be of use in detecting forgery, for the change of colour affords evidence as to whether all the writing has been performed with the same ink.

The Effects of Magnesia on Vegetation, by Major-General Scott, C.B., F.R.S.- The author's conclusion, drawn from numerous experiments, is that there is overwhelming evidence against the notion that soil naturally contains so much magnesia that an extra supply will be of little or no benefit. There are strong grounds for supposing that magnesia, like phosphoric acid, is not only an essential ingredient of plants, and aids in their nutriment, but also that it determines the beneficial action of other ingredients.

On the Action of Oils on Metals, by William H. Watson.Most oils attack copper and iron, but not to the same extent. Some act much more on copper than on iron, and vice versad.

On Bleaching-Powder Residues, by J. F. W. Hodges.-To extract active chlorine from ro grains of bleaching powder, so 
that it does not react with starch paper, 5,000 cub. cents. of water are required. Even then it reacts with iodine and starch. The amount of residue varied between 22 and 30 per cent. of the total quantity of bleaching powder. This residue, on treatment with acid, evolved a minute amount of active chlorine ; the residue, applied to cotton and treated with acid, has no bleaching or injurious action.

On the Coal-seams of the Eastern portion of the South Wales Basin, and their Chemical Composition, by J. W, Thomas.

On the Refraction Equivalent of Diamond and the Carbon Compounds, by J. H. Gladstone, Ph.D., F.R.S.-The specific refractive energy (that is, the refractive index $-\mathrm{I}$ divided by the density) of numerous compounds of carbon was determined by Gladstone and Dale in 1863 . From their experiments it was found that carbon uncombined, as in the diamond, and also in combination with hydrogen and oxygen, has a specific refractive energy of $5^{\circ} \mathrm{O}$. Yet in compounds of the aromatic series, where several atoms of carbon are united by more than one bond, the refraction equivalent is raised about $2^{\circ} \mathrm{O}$. This does not embrace the facts that the terpenes have a refraction equivalent lying between 2 and 4 over the calculated numbers; that the cinnamyl compounds also show abnormality; and that hydrocarbons containing a greater number of atoms of carbon than of hydrogen increase in refractive energy at a rate more rapid than theory demands. Thus naphthalene shows a surplus of $16^{\circ} 4$, anthracene of $31^{\circ} 7$, and pyrene of $43^{\circ} 6$ over the calcu. lated numbers.

Dr. Bedson, who has been recently investigating the subject in conjunction with $\mathrm{Mr}$. W. Carleton Williams, remarked that sufficient allowance had not been made for dispersion in the lastmentioned instances; that from their experiments they have found the degree of concentration of the solution to exercise a marked infuence; and he suggested that in naphthalene, anthracene, and pyrene, the molecules are much more complex than in benzene, for several groupings of carbon atoms are noticeable, among them two groups in which an atom of carbon is united to other atoms of carbon by all four bonds.

On a New Process for the Production from Aluminous Minerals of Sulphate of Alumina from Iron, by J. W. Kynaston.-After a preliminary sketch of the various methods of preparing sulphate of alumina in a state of greater or less purity from various minerals containing it, the author describes his own process for preparing it free from iron from bauxite, a silicate and titanate of alumina and iron. This he does by treating it with a mixture of oxalic and hydrochloric acids, allowing it to stand for a week or ten days. The insoluble portion is freed from oxalic acid by repeated washing, and the residue converted into sul. phate of alumina by treatment with sulphuric acid. This product is almost free from iron. The oxalic acid is recovered by precipitation with lime, and subsequent decomposition of the salt with sulphuric acid. The expense of this process has prevented its adoption. The author has now devised a process whereby the iron is precipitated as arsenite, and then by means of carbonate of lime neutralising any free acid, and at the same time producing some tetrabasic sulphate of alumina. The remaining ferrous iron is then removed by addition of ferrocyanide of lime. The blue precipitate is induced to settle by addition of a little sulphate of iron or zinc. Excess of arsenic is precipitated with sulphide of lime. This process is at present in operation at St. Helen's.

On a New Process for separating Silver from Copper Ores and Reguluses, by William Henderson.-This process is applicable to calcined Spanish pyrites containing a large proportion of arsenic before calcination. The "raw regulus," when fitsed with 20 per cent. of its weight of sodium bisulphate, yields metallic silver in large amount. The iron and copper are converied into oxides, while the silver remains as sulphate, and may be extracted from the residue with water. The process has as yet been worked only on a small scale.

\section{SECTION C.-GEOLOGY}

Notes on the Submarine Geology of the English Channel of the Coast of South Devon, by Mr. A. R. Hunt, F.G.S.-Attention was called to the presence of large detached blocks of stone over an area extending from S.S.W. of the Start to S. of the Eddystone. One of these blocks in Torquay was stated to weigh $9 \frac{1}{4} \mathrm{cwt}$, another not landed measured 3 feet 6 inches. They consisted of granite, conglomeritic grit, serpentine, and abbrogubbon.
A paper On the Site of a Palcolithic Implement Manufactory at Crayford, Kent, by Mr. F. C. Spurrell, was read by Prof. Dawkins. This occurred in brick-earths containing a large number of extinct mammalia, and on the same horizon with them. They were probably manufactured on the spot, by the old dwellers, and belong to the same type as the implements of St. Acheul. Many of the specimens when found were completely shattered, and the fragments were united by $\mathrm{M}$.. Spurrell

On the Island of Torghatten, Norway, and on the Influence of Foints on Denudation, by Prof. W. J. Sollas. Describes a conical or hat-shaped mountain, traversed by a tunnel 600 feet in length, through which the light can be seen. The rock is compact gneiss, roche moutonées occur up to the level of the platform, which terminates slightly below the entrances to the tunnel, which are somewhat lower than the centre. Attributes its origin to mechanical disintegration, aided by joints.

On the Contortion of a Ouartz Vein in Mica Schist from Bodö, Norway, by Prof. W. J. Sollas. Describes excessively contorted band of quartz between foliation planes.

On the Geological Age and Relations of the Sewalik and Pikermi Vertebrate and Invertebrate Faunas, by W. T. Blanford.-The deposits from these two areas have both been referred to the Miocene, and contain an analogous fauna. The Sewalik beds are a portion of a great Tertiary area crossing India from Assam to Sind. The lower beds are nummulitic and marine, the upper series entirely freshwater. Of 48 genera in the Sewalik fauna, with 93 species in the Siwalik area, 12 are peculiar, 4 genera do not occur higher than the European miocene, 25 genera are recent, including cats, dogs, bears, true elephants, antelopes, and sheep. The lower Manchhar mammalian fossils were shown to be older than the Sewalik series, but are newer than the Upper Miocene, and therefore the Sewalik series is referable to the Pliocene. The Sewalik fauna contains six reptiles, of which three are still living. Ruminants are numerous in both the Sewalik and the Pikermi deposits; the latter rest on a bed with Pliocene marine mollusca. Suggests as the climate grew colder in Pliocene times the Miocene mammals migrated southwards.

On the Relations to be established between Coast-line Direction represented by Great Circles on the Globe and the Localities marked by Earthquakes in Europe, by Prof. J. P. O'Reilly.-Refers to the rectilinear direction of coast-lines as that between Carnsore and Wicklow heads, this if produced and regarded as part of a great circle which passes through the Dykes of Southern Scotland and corresponds to the east coast-line of Scotland north of the Firth of Tay, the Carnsore coast-line direction being strictly parallel to the strike of the rocks west of it, and of the termination of the great masses of granite of Kilkenny. Refers to the linear direction of the limit of earthquake-movement in Southern Sweden, and he suggests the similarity of direction in coast-lines and the boundaries of earthquake-movement have the relation to each other of cause and effect, the coast-line being the result of slips along the lines of weakness produced by earthquakes.

On the Sandstones and Grits of the Lower and Middle Series of the Bristol Coal-fields, by E. Wethered.-These carboniferous sandstones are composed of angular grains, those of the Millstone Grit being the least so. He describes an intermediate stage between grit and soft clay as "hard duns," of a hardness of 7 , being a rock that scratches glass. The Brandon Hill grit yielded on analysis 98.5 per cent. of silica ; it is used for mining purposes and for brickmaking. The thickness of the Pennant grit is 970 feet, associated with coal-measures of 2,000 feet thickness. He regards the "Pennant grits" as a local deposit, and as occurring on more than one horizon. The "Duns" contain more alumina, and he considers the silicates (except the silicates of alumina) by the action of carbonic acid gas.

A paper On the Hiatus said to have been found in the Rocks of West Cork, by Mr. G. H. Kinahan, was read by Mr. Ussher.The following classification was given :-

\begin{tabular}{|c|c|c|}
\hline GRIFFITHS & PROF. TUKES & Prof. HuLL \\
\hline Carboniferous slate. & Carboniferous slate. & Carboniferous slate \\
\hline $\begin{array}{l}\text { Yellow Sandstone. } \\
\text { Old Red Sandstone. } \\
\text { Silurian. }\end{array}$ & $\begin{array}{l}\text { Upper Old Red. } \\
\text { Lower Old Red. } \\
\text { Glengariff grit. }\end{array}$ & $\begin{array}{l}\text { Kiltorcan beds. } \\
\text { Glengariff beds (Silu- } \\
\text { rian). }\end{array}$ \\
\hline
\end{tabular}

The author rejects Prof. Hull's view, that an important hiatus and unconformability occurs above the Glengariff beds, and he considers that a complete sequence of formations occurs from the Silurians up to the Carboniferous. 
Note on the Range of the Lower Tertiaries of East Suffolk, by Mr. W. H. Dalton, was read by Mr. Whitaker.-Describes scetions obtained in deep wells and borings through the drift. One at Yarmouth proved the chalk to be 500 feet from the surface; between the drift and the chalk there being no less than 300 feet of Lower Tertiaries. These wells also prove the surface of the chalk to be an inclined plane beneath the Tertiaries, and the surface of the Tertiaries beneath the drift also obeys the same law. At Brandfield the chalk was found at 48 feet below the mean sea-level.

Proof of the Organic Nature of Eozoon Canadense, by $\mathrm{Mr}$. Charles Moore,-Refers to the opinion of Prof. Moebius, of Kiel, of specimens supplied him by Dr. Carpenter, that the eozoonal structure is referable to the mineral kingdom, which view is also taken by Dr. Otto Hann of Ruthlengen, and describes his own examination of a specimen of Laurentian rock from Canada, supplied him by Dr. Carpenter, and of others by $\mathrm{Mr}$. J. Hind. A specimen weighing twenty grains was decalcified and placed in stoppered bottles in water filtered through asbestos ; this when magnified was found to reveal a clear siliceous-looking fibroid growth of organic structure of black gum and olive colours. These curled fibres can only be compared to a bit of polished golden wire. They are formed of three round golden close-set columns. It is not a parasitic shell, for when dry it is rigid; but when moist, curved and curled specimens are flexible. They are not unlike the pedicle to which the capsule of some Rhizopoda are attached; but in such a case they must have been devoured by the eozoon, which is not probable. In addition there is another organic structure, not thicker than a spider's web, like mycelium growth of the present day, and also anomalous bodies, possibly the ova, or gemmules of forams. Refers to a similar mycelium growth, as in Eozoon found on nummalites; also similar structures in the Globigerina of the Challenger dredgings from the bottom of the Atlantic.

On the Post-Tertiary and Glacial Deposits of Kashmir, by Lieut.-Col. Godwin-Austen,-Refers to the work done by Mr. F. Drew. The author is of opinion that certain deposits containing human remains were deposed by a lake, still existing, but formerly of larger dimensions. Refers the older beds to the age of the upper conglomerates of the Upper Sewaliks. $\mathrm{He}$ referred to the deposits at different heights on the banks of the Indus, extending up to eighty feet above the river, forming cliffs or bluffs with angular, probably glacial, deposits. The next terraces occurred at I 20 feet, and these again had still higher beds above them, and the author believes the whole of the series reach not less than I,000 feet in thickness.

On the Fault-Systems of Central and West Cornwall, by J. H. Collins.-Fifteen distinct fault-systems, and possibly far more; the older system is newer than the Carboniferous; when the earliest was produced, the country was much the same as it is now. The granite juction-faults are always filled up with schist; these oldest faults are succeeded by the elvan veins; these cut a fissure in the slate rock, which has been bent and distorted, and often faulted; these are nearly all of precisely the same age. The tin-lodes are the next, followed by a second system, crossing the older in an oblique direction. Of still newer date are the east and west copper veins. The eighth system is also copper, known as the Caunta copper lodes. Then followed the ninth system, or cross-courses, running north and south, generally only containing oxide of copper and quartz, The later lodes never contained tin; in the last only quartz. The fifteenth set are the "alluvial faults;" the ancient alluvial tin gravels are traversed by them.

On the Geology of the Balearic 1slands, by Dr. Phené.-Refers to the cave deposits in the grottos of Antiparos and of the almost mountainous dimensions of the external deposits called Pambuk Kalesi at Hierapolis, in Anatolia. He describes the superb caverns near Artâ, la Cueva de la Hermita, in Majorca. The southern portion of the island is Miocene, the more northern begins on the east with a sea-coast of Devonian, followed by Triassic and Jurassic deposits, again succeeded by Devonian. The cave occurs in a fragment of Miocene cliffs. In its vast size and its magnificent columns of uniform thickness it may be compared with the proportions of Westminster Abbey; its dimensions are exceedingly vast, and its lines resemble Gothic and Moorish architecture in their delicate traceries.

On some Pre-Cambrian Rocks in the Harlech Mountains, by Dr. Hicks.-Describes the Cambrian area of the Harlech Mountains, where he considers rocks occur equivalent to the felsitic group of Bangor of pre-Cambrian age, and he believes the Harlech rocks of Prof. Sedgwick rest on these ancient rocks, which form a part of a very ancient anticlinal, the conglomerates at the base of the Harlech group being derived from the felsitic pre-Cambrian rocks beneath.

On the Action of Carbonic Acid on the Limestone, by Prof. Boyd Dawkins, F.R.S. - Caves in the limestone are to be looked upon as subterranean watercourses, which are produced partly by the dissolving action of the carbonic acid in the rainwater, and partly by the mechanical action of the streams flowing through them. The insoluble carbonate of lime in the rock is changed into the soluble bi-carbonate and carried away in solution. The additional atom of carbonic acid, however, is in a condition of unstable chemical combination, and if it be removed either by evaporation or by the action of the free current of air, the insoluble carbonate of lime is at once deposited. Hence it is that some caverns have their walls covered with a drapery of stalagtite and the little straw-like pendants from the roof formed round the edges of each drop gradually become developed into columns of various sizes. The stalagmitic pedestals also rise from the floor where a line of drops falls from the roof and ultimately unite with the column let down from above. On the surface, too, of the pools an ice-like sheet of stalagmite gradually shoots across from the siches, and sometimes where the water is still covers the whole surface. Admirable illustrations of all these processes are to be seen in the caves of Pembrokeshire, and especially in the Fairy Cave on Caldy Island.

The rate of the accumulation of carbonate of lime depending primarily upon the access of water and the free access of air, both being variable, varies in different places. Sometimes it is very swift, as for example in the Ingleborough Cave, where a series of observations by Prof. Phillips, Mr. Farrar, and the author extending over the years from 1845 to 1873 give the annual rate at 2946 inch. It is obvious therefore that all speculation as to the antiquity of deposits in cases which are based on the view that the accumulation is very slow is without value.

The mountain limestone ravines and passes are to be viewed in the main as caverns formed in the manner above stated, which have lost their roofs by the various sub-aërial agents which are ever at work attacking the surface of the limestone. If any of these be examined, it will be seen that the tributary caves open on their sides, and in some cases the ravine itself is abruptly terminated by a cavern.

On a Raised Beach with Diluvial Drift in Rhos Sili Bay. Gower, by Prof. Prestwich.-This beach is coextensive with a cliff $\mathbf{x} \frac{1}{2}$ mile in length, at the south-west corner of the peninsula of Gower. The cliff is 50 to 80 feet in height, sloping from the top to the parallel range of Old Red Sandstone, consisting of red sandstones and quartz conglomerate. The cliff consist of lenticular, rudely stratified, re-arranged material 40 to 50 feet in thickness ; contains neither shells nor bones, and rests on a well. rolled raised beach, with pebble from the Carboniferous lime. stone, coal-measures, and other measures, its average thickness 8 to 10 feet, but occasionally it is piled up much higher; it contains shell of Littorinus, Purpura lapillus, Turritela terebra.

Prof. Prestwich also read a paper On the Geological Evidence of the Submergence of the South-West of Europe during the Early. Human Period.-Refers to the residual deposits, consisting of gravel, fragments of rock, exhibiting little or no bedding; of this group is the "Warp" of the Rev. Mr. Trimmer, the "Trail" of Rev. O. Fisher, the result of great cold and weathering; "Head," by Mr. Godwin-Austen, derived from cliffs during severe climate; others have referred it to the denudating action of ice and snow, rain action, and to "waves of translation." All these groups the author correlates; in early days all superficial deposits were referred to the "diluvial theory" of Dr.'Buckland. Refers to old river terraces proving the gradual wearing away of the valleys ; but the author would revive a portion of the old "diluvial theory " for certain other deposits. He groups the Loess, warp, head, trail, and alluvial deposits occupying the centres of broad valleys, into one group, produced by a flood caused by a great temporary submergence of the land and its subsequent re-eleva. tion, which spread material without rounding the fragments. Coarse délris always to be traced from higher to lower levels; shells are rare, debris is local, and these beds cover all others, at all levels. Refers to the "warp" of the Thames, as difficult to distinguish from London clay, gradually becoming more gravelly on the lower slopes, and merging into the ordinary valley gravels. The trail lying on the gault of Maidstone was then described, capping the hill, and following down the slope of the hill with an increasing thickness on the lower slopes. 
The "trail" of the Severn derived from the northern hills is spread over the central flat regions, and forms the Cotswolds to the east. "Head" is stated to cover all the old beaches of the south of England and of Wales, as at Rottingdean, and Berling Gap, near Worthing, the low cliff behind the South-Eastern station at Dover, both sides of the Bristol Channel, between Calais and Blanc Nez, reaching a thickness of 80 to 100 feet, the height being limited only by the heights of the ground between. The beach often contains erratic boulders, and he refers the raised beach to a period during the glacial episode, but at a time when the present coast-line had obtained. Sangatte Cliff contains delicate land shells and the remains of the mammoth; ground palæolithic implements. Others occur at Cherbourg and in the Isle of Ré between there and Gibraltar none are known to occur, though they possibly may be present.

Refers to the clay-gravel or head overlying the raised beach of Portslade, between Brighton and Chichester as containing land shells, palæolithic implements, and bones of land animals; raised beach and head of Guernsey; these deposits and others on the French chalk, Belgium, and the Rhine country he considers to be due to causes other than the deposition of fluviatile material, marine deposits, ice or snow slopes or ice-cap. The débris is not a talus, for it slopes as a small angle and increases in thickness in retreating from the hill and slope. The submergence destroyed the palæolithic man and many of the older animals, and amounted to more than $\mathrm{r}, 000$ feet.

Prof. W. J. Sollas read papers On a Striated Stone from the Trias of Portishead; On the Action of a Lichen on Limestone, and On Sponge Spicules from the Chalk of Trimmingham, Norfolk.

On the Geological Literature of Wales, by Mr. W. Whitaker, who gave a list of all the publications that have referred to Welsh geology from the seventeenth century to 1873 , contaiaing more than 500 entries.

Sketch of the Geology of British Columbia, by Dr. G. M. Dawson, jun., describes littoral deposits of Miocene age, capped by volcanic rocks in the Queen Charlotte Islands. Cretaceous rocks from the Upper Neocomian to the Upper Chalk, equivalent to the Chico group of California, yield the bituminous cols of Manaimo; anthracite occurs at a somewhat lower horizon. The pre-Cretaceous rocks are contorted and disturbed, and those of Vancouver Island are probably of Carboniferous age, and are associated with volcanic deposits; rocks probably Huronian occur in Queen Charlotte Islands. In the Rocky Mountains are Carboniferous and Devonian limestones and Triassic sandstones.

Notes on the Occurrence of Stone Implements in the Coast Laterite, South of Madras, and in High-level Gravel and other Formations in the South Mahratta Country, by Mr. R. Bruce Foote.-The author describes high-level (partly laterite) gravels of fluviated and lacustrine origin in the basin of the Gatpratha, and Malprabha tributaries of the Kistna in the South Mahratta country yielded large numbers of several types. He then alluded to the occurrence of well-shaped implements, chiefly of the pointed oval type, and made of hard siliceous limestone, in a great talus of limestone and Deccan trap block cemented by calcareous tufa into a great breccia-conglomerate. This occurs along the foot of the hills north of Kistna and west of Soorapoor, in the Nijam's territory. The implements were found worked out in gullies.

On the Pre-Glacial Contour and Post-Glacial Denudation of the North-West of England, by Mr. De Rance, F.G.S., Assoc. Inst. C.E.-The country described is that lying between the Silurian mountains of North Wales and the Lake District, and bounded east by the Carboniferous hills of the Pennine chain. The plains of Lancashire and Cheshire lying at their feet are deeply covered with glacial drift, reaching in one instance, near Orms. kirk, a thickness of no less than 230 feet. The deep valleys of the Lake District had attained their present proportions before the Glacial epoch, during which the lakes were excavated, in the case of Windermere, to a depth of 230 feet, or deeper than the English Channel between Boulogne and Folkestone, the bottom of the lake being 100 feet beneath the sea-level. In the valleys of the mountain country the marine glacial deposits are not present, having been re-excavated ont by later glaciation, where originally present. In Lancashire, Cheshire, and Flintshire the marine drift occupies an extensive area, and valleys like those of the Ribble and the Irwell, nearly 200 feet in depth, have been excavated in and through them; occasionally the bottom of the valley is beneath the sea-level, pointing to the land being higher in pre-glacial times. A terrace of post-glacial deposits fringes the glacial area at, and often below, the sealevel, consisting of peat with a forest at the base, resting on a marine post-glacial deposit; the peat-beads are found beneath the sea-level to an extent, in one case, of about 70 feet, and it was pointed out that an elevation of this amount would connect Lancashire, Cheshire, and much of North Wales with the Isle of Man.

\section{SECTION D-BIOLOGY}

Mr. Gwyn Jeffreys moved and Prof. Rolleston seconded a vote of thanks to Dr. Günther for his address, which was supported by Dr. Sclater. Prof, Rolleston suggested that in every large town a small rate should be levied in favour of a local museum, which is actually done in Liverpool. He also insisted on the importance of a lecture-room in connection with the national natural history collections.

On the Classification of Cryptogams, by Alfred W. Bennett.In the most recent classification of cryptogams, that by Sachs, in the fourth edition of his "Lehrbuch," he divides Thallophytes (including characeæ) into four classes of equal rank, Protophyta, Zygosporeæ, Oosporeæ, and Carposporeæ. It is proposed in the present paper to retain Sachs' class of Protophyta for the lowest forms of vegetable life; but to restore the primary division of the remainder of thallophytes into Fungi and Algæ, as being more convenient to the student, and at least as much in accordance with probable genetic affinities.

Asre gards minor points the characeæ are removed altogether from thallophytes, and again constituted into a separate group of the first rank; the myxomycetes are regarded as presenting a low type of structure, scarcely raised above the protophyta, and not exhibiting true sexual conjugation; volvox and its allies are removed from the zygosporeæ to the oosporeæ; and the phæosporea are separated off as a distinct order from the fucacex.

The thallophytes are therefore first of all divided into three primary classes:-Protophyta, FungI, and AlG.e. The protophyta are divisible into two sub-classes, Protomycetes and Protophycea. The protomycetes consist of a single order, the schizomycetes, of which saccharomyces is regarded as an aberrant form. The protophyceæ are composed of the protococcaceæ (including palmellaceæ and scytonemeæ), nostocacex, oscillatorieæ, and rivularieæ. The Myxomyceles are treated as a supplement to the protophyta. The fungi are made up of three sub-classes, employing in the main the same characters as Sachs, but, in their terminology, using the syllable "sperm" instead of "spore." The first division, the Zygomycetes (or zygospermez achlorophyllaceæ), is composed of the mucorini only (including the piptocephalidæ). The second, the Oomycetes (or oospermeæ achlorophyllaceæ), comprises the peronosporeæ and saprolegnieæ (including the chytridiacex). The third, the Carpomycetes (or carpospermex achlorophyllacex), is made up of the uredineæ, ustilagineæ, basidiomycetes, and ascomycetes, the lichenes being included in the last as a sub-order. The algæ are arranged under three corresponding sub-classes. The Zygothycee (or zygospermeæ chlorophyllacer) is made up of the following orders :-Pandorineæ, hydrodictyex, confervaceæ (under which the pithophoraceæ may possibly come), ulotrichaceæ, ulvaceæ, botrydieæ, and conjugatæ (the last comprising the desmidiex, diatomaceæ, zygnemaceæ, and mesocarpeæ). The Oophycece (or oospermeæ chlorophyllaceæ) includes the volvocinex, siphoneæ (with the nearly allied dasycladeæ), sphæropleaceæ, œdogoniaceæ, fucaceæ, and phæosporeæ. The Carpophycee (or carpospermeæ chlorophyllaceæ) is made up of the coleochæteæ and florideæ.

The CHARACE e constitute by themselves a group of primary importance. The MUSCINEA are unchanged, comprising the Hepatica and Musci (including sphagnaceæ). In VASCULAR CRYPTOGAMS it is proposed to revert to the primary distinction into Isosporia and Ileterosporia as most in accordance with probable genetic affinities. The isosporia consist of the filices (including ophioglossacex), lycopodiacex, and equisetacex. The heterosporia comprise the rhizocarpex and selaginellacex. In the terminology of the heterosporia the inconvenience and incorrectness are pointed out of the use of the terms "macrospore" and "macrosporangium;" and it is proposed to call the two kinds of spores and their receptacles respectively microspore, megaspore, microsporangium, and megasporangium; or better, in reference to their sexual differentiation, androspore, gynospore, andro. sporangium, and gynosporangium.

A Reformed System of Terminology of the Reproductive Organs of the Cryptogamia, by Alfred W. Bennett and George Murray. 
-After giving illustrations of the present chaotic state of cryptogamic terminology, the authors proceed to state that the object they have kept in view is to arrive at a system which shall be symmetrical and in accordance with the state of knowledge, and which shall at the same time interfere as little as possible with existing terms. A few new terms are introduced, but the total number is greatly reduced.

In the fourth edition of his "Lehrbuch" Sachs defines a "spore" as " a reproductive cell produced directly or indirectly by an act of fertilisation," reserving the term "gonidium" for those reproductive cells which are produced without any previous act of impregnation. The practical objections to this limitation of terms are pointed out, and it is proposed to restore the term spore to what has been in the main hitherto its ordinary signification, viz., any cell produced by ordinary processes of vergetation, and not by a union of sexual elements, which becomes detached for the purpose of direct vegetative reproduction. The spore may be the result of ordinary cell-division or of free cell-formation. In certain cases (zoospores) its first stage is that of a naked mass of protoplasm; in rare instances it is multicellular, breaking up into a number of cells (polyspores, composed of merispores, or breaking up into sporidia). Throughout thallophytes the term is used in the form of one of numerous compounds expressive of the special character of the organ in the class in question. Thus, in the protophyta and mucorini we have chlamydospores; in the myxomycetes, sporangiospores; in the peronosporeæ, conidiospores; in the saprolegniea, oophycex, and some zygophyceæ, zoospores in the uredinex, teletutospores, acidiospores, uredospores, and sporidia; in the basidiomycetes, basidiospores; in the ascomycetes (including lichenes), conidiospores, stylospores, ascospores, polyspores, and merispores; in the hydrodictyex, megaspores; in the desmidiex, anxospores; in the volvocinere and mesocarper, parthenospores; in the siphonere and botrydiex, hypnospores; in the oedogoniaceæ, androspores; in the florider, tetraspores and octospores. The cell in which the spores are formed is in all cases a sporangium.

In the terminology of the male fecundating organs very little change is necessary. The cell or more complicated structure in which the male element is formed is uniformly termed an antheridium, the ciliated fecundating bodies antherozoids (in preference to "spermatozoids"). In the florideæ and lichenes, the fecundating bodies are destitute of vibratile cilia; in the former case they are still usually termed "antherozoids," in the latter "spermatia," and their receptacles "spermogonia." In order to mark the difference in structure from true antherozoids, it is proposed to designate these motionless bodies in both cases polbinoids; the term "spermogonium" is altogether unnecessary, the organ being a true antheridium.

A satisfactory terminology of the female reproductive organ presents greater difficulties. The limits placed to the use of the term spore and its compounds require the abandonment of "oospore" for the fertilised oosphere in its encysted stage anterior to its sermentation into the embryo. The authors proposs the syllable sperm as the basis of the various terms applied to all those bodies which are the immediate result of impregnation. It is believed that it will be found to supply the basis of a symmetrical system of terminology which will go far to redeem the confusion that at present meets the student at the outset of his researches. For the unfertilised female protoplasmic mass, it is proposed to retain the term oosphere, and to establish from it a corresponding series of terms ending in sphtre. The entire female organ before fertilisation, whether unicellular or multicellular, is designated by a set of terms ending in gonium.

In the zygomycetes and zygophycex, the conjugated zygo. spheres, or contents of the zygogonia, constitute a sygosperm; in the oomycetes and oophycese the fertilised oosphere, or contents of the oogonium, is an oosperm; in the carpophycere the fertilised carposphere, or contents of the carpogonizm, constitutes a carposperm. In this last class the process is complicated, being effected by means of a special female organ which may be called the trichogonium (in preference to "trichogyne"). The ultimate result of impregnation is the production of a mass of tissue known as the cystocarp (or "sporocarp"), within which are produced the germinating bodies which must be designated car. pospores, since they are not the direct results of fertilisation. In the carpomycetes no similar process is at present known. Any one of these bodies which remfins in a dormant condition for a time before germinating is a hypnosperm. In the cormophytes (characee, muscinex, and vascular cryptogams) the fertilised archesphere, or contents of the archegonium, is an archesperm.

In the basidiomycetes, ascomycetes, and some other classes, it is proposed to substitute the term fructification for " receptacle," for the entire non-sexual generation which bears the spores,

In the discussion which followed, Prof. Rolleston and Prof.

I. B. Balfour took part, the latter objecting to the proposed alterations in classification and terminology in several points. He believes all the schizomycetes to be degraded ascomycetes, and prefers Sachs' classification of the vascular cryptogams. He also objected to the use of the term "sperm" in the sense proposed.

Further Remarks on the Mollusca of the Mediterranean, by J. Gwyn Jeffreys, LL.D., F.R.S.-At the Bradford Meeting of the Association in I873 I made some remarks on the Mollusca of the Mediterranean, and gave a list of those species which had not yet been noticed as Atlantic, being then $\mathbf{2 2 2}$ in number. Since that time many of the species have been discovered in the Atlantic, or been ascertained to be varieties of other well-known Atlantic species. This list will be found in pages $\mathrm{Ir}_{3}$ to 115 of the Report. I will now give a list of those Mediterranean species which are also Atlantic, or varieties of other species, on the authority of the Marquis de Monterosato, the Marquis de Folin, Dr. Fischer, the IRev. Mr. Watson, and myself.

BrachIOPODA.-Argiope cordata, Risso; Thecidium mediterraneum, Risso. ConChIrerA. - Pleuronectia lavis, Jeffreys, a monstrosity of Pecten similis; Mytilus minimus, Poli ; Nucula convexa, $\mathrm{J} .=L$. aegensis, Forbes, young ; Leda oblonga, J. = $L$. micrometrica, Seguenza; $L$. subrotunda, J. $=L$. minima, Seg. ; Solenella cuneata, J. (Malletia); Venus cygnus, Lamarek $=V$. nux, Gmelin; Pecchiolia insculpta, J. (Verticordia). GastroPODA.-Emarginula adriatica, O. G. Costa ; Trochus scabrosus, $\mathrm{J} .=T$. gemmulatus, Philippi ; Fossarus costatus, Brocchi ; Rissoa caribea, D'Orbigny ; $R$. mudis, $\mathrm{Ph}$.; $R$. maderensis, J.; Cacum chiereghinianum, Brusina $=C$. glabrum, Montagu, variety; Vermetus triquetra, Bivona; Scalaria cantrainei, Weinkauff; Odostomia polita, Biv. ; O. tricincta, J.; $O$. fasciata, Forb.; Eulima micrastoma, Brus.; $E$. jeffreysiana, Brus.; Natica dillweynii, Payraudeau; N. marmorata, H. Adams; Solarium pseudoperspectivum, Brc.; Xenophora mediterranea, Tiberi ; Cerithium costatum, Da Costa ; C. elegans, De Blainville; Triton seguenza, Aradas and Benoit $=T$. nodifer, Lam., var.; Lachesis folinea (Delle Chiaje) Ph.; Cassidaria echinophora, Linné ; probably C. tyrrhena, Chemnitz, is a variety; Defrancia hystrix, De Cristofori and Jan. ; Pleurotoma pusilla, Scacchi $=P$. multilineolata, Deshayes, var.; Cyproa physis, Brc.? Uiriculus striatulus, J.; Akera fragilis, J.; Diphyllidia lineata, Otto; $D$. pustulosa, Sc. Total $4 \mathrm{I}$ species.

This reduces the number of supposed exclusively Mediterranean species from 222 to 181 ; and it must be borne in mind that the Atlantic Nudibranchs and Cephalopods have never been completely worked ont. Philippi's list of Mediterranean Nudibranchs and Verany's list of Mediterranean Cephalopods amount to 58 out of the above residuc of $18 \mathrm{r}$. When further researches by dredging have been made in the North Atlantic, I believe the difference between the Mollusca in that extensive ocean and in the Mediterranean will be still more diminished, if it do not in time altogether disappear.

\section{THE MEETING OF THE IRON AND STEEL INSTITUTE AT DÜSSELDORF}

THE rccent meeting of the Iron and Steel Institute at Diisseldorf was peculiarly interesting, as illustrating the interriational character of the Society, and also because of the opportunity which it afforded to English members of studying German workshops and methods of manufacture. The papers which were read were mostly by German anthors, and dealt with many subjects of importance to those interested in the manufacture of iron and steel. Many of them were of too technical a character to be noticed at length in these pages, but as an exception we may mention the paper on "The Dephosphorisation of Iron in the Converter," by Herr J. Massenez of Hoerde in Westphalia.

This subject has received great attention at the recent meetings of the Institute, but not more so than its importance deserves. We referred at length to the basic process of dephosphorising pig iron, when reviewing the proceedings at the spring meeting, and the paper now before us contains a most satisfactory record of results since attained, together with much valuable informa tion as to the chemical changes which take place during the conversion. The method is best known by the names of the 